\title{
Tunnel vision in current chemicals management cannot deal with the unknown risk of synthetic chemicals in aquatic systems
}

\author{
Abordagem estreita no manejo atual dos poluentes químicos limita compreensão dos \\ riscos de novos poluentes sintéticos para os ecossistemas aquáticos
}

\section{Anna Sobek ${ }^{1 *}$ (i) and Emma Undeman² (D)}

\begin{abstract}
${ }^{1}$ Department of Environmental Science and Analytical Chemistry - ACES, Stockholm University,
\end{abstract} 10691, Stockholm, Sweden

${ }^{2}$ Baltic Sea Centre, Stockholm University, 10691, Stockholm, Sweden

*e-mail: anna.sobek@aces.su.se

Cite as: Sobek, A. and Undeman, E. Tunnel vision in current chemicals management cannot deal with the unknown risk of synthetic chemicals in aquatic systems. Acta Limnologica Brasiliensia, 2019, vol. 31, e106.

Abstract: Chemicals management is focused around the hazard, exposure and risk assessment of single chemicals. This is a slow process which cannot keep pace with chemical innovation and development of use. Environmental monitoring focuses on few, and well-known, chemicals. As a consequence, the majority of all chemicals emitted to the aquatic environment remain unstudied, and so does their risk. We conclude that to understand how chemical pollution affects aquatic ecosystems, requires reformation of current chemicals management, moving away from the single chemical approach. It requires increased transparency regarding chemical content in materials, products and articles, and importantly, a management system that covers different aspects of the many unknowns related to chemical pollution of aquatic systems. This implies for instance, environmental monitoring that screens for a wide range of chemicals and effects, and that is able to detect more unexpected effects of chemical pollution than what is possible today.

Keywords: chemical pollution; chemicals management; monitoring; aquatic; risk.

Resumo: A gestão e o manejo de poluentes químicos são focados na periculosidade, exposição e avaliaçáo de risco. Esse processo é lento e náo acompanha o surgimento de novas substâncias e o desenvolvimento do seu uso. $\mathrm{O}$ monitoramento ambiental foca em poucas substâncias que são bem conhecidas. Consequentemente, a maioria das substâncias emitidas e seus efeitos nos ecossistemas aquáticos permanecem desconhecidos. Concluímos que para se entender como poluentes químicos afetam os ecossistemas aquáticos é necessária a reformulação da atual forma de gestáo e manejo atual, abandonando a abordagem sobre avaliação individual dos poluentes. É necessária uma maior transparência sobre o conteúdo químico dos materiais e produtos em geral e, principalmente, que a gestâo considere diferentes aspectos e as incertezas relacionados à poluição química em ecossistemas aquáticos. Isso implica, por exemplo, em práticas de monitoramento ambiental que avaliem ampla gama de diferentes poluentes e seus efeitos, viabilizando a detecçấo de mais efeitos inesperados de poluentes químicos do que se faz atualmente.

Palavras-chave: poluição química; manejo e gestão de produtos químicos; monitoramento; aquático; risco. 


\section{Introduction}

\subsection{Chemical use in a changing world}

Our modern society relies on the use of synthetic chemicals, driven by for instance a need for curing disease, controlling pests and enhancing material properties. An unwelcome side-effect is contamination of aquatic environments by man-made hazardous compounds, which consequently has been on the environmental agenda for half a century (Carson, 1962; Jensen et al., 1969). Our awareness of risks associated with chemicals has evolved over time and with that chemicals legislation and management, but also the use of chemicals (Figure 1). In pace with global population growth, economic development and innovation, global chemical production has continuously increased, and is expected to increase in the future (CEFIC, 2018; Wilson \& Schwarzman, 2009). The increase over time in production of synthetic chemicals since the 1950's can be added to the list of exponentially increasing socio-economic indicators of what has been called "the Great Acceleration" (Steffen et al., 2015), and even outpaces other agents of global change, such as rising atmospheric $\mathrm{CO} 2$ concentrations, nutrient pollution, habitat destruction and biodiversity loss (Bernhardt et al., 2017).

\subsection{High numbers of chemicals in use}

The exact number of chemicals in use is unknown. There are about 348000 regulated chemicals globally (CAS, 2018). In the European Union (EU), there are currently about 21400 chemicals registered for use in industrial applications (ECHA, 2018). In addition, there are other compound groups covered by specific legislation such as pharmaceuticals,

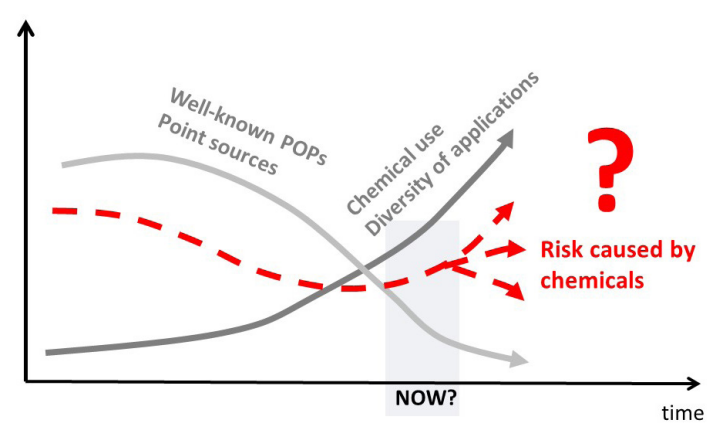

Figure 1. Emissions of well-known persistent organic pollutants (POPs) have decreased over time, whereas modern chemical use and diversity of applications increase, and with that potential risk caused by chemicals. pesticides, chemicals in personal care products and food additives. It has been expressed that society is currently going through a "chemical intensification" due to the continuously increasing production and use of more advanced chemicals in everyday products (UNEP, 2013).

\subsection{Increasing chemical use challenges society}

Planetary boundaries define a safe operating space for humanity. The boundaries define how much of an antropogenic stressor Earth's environmental systems can tolerate without causing irreversible harm (Rockström et al., 2009). One such boundary is the atmospheric concentration of $\mathrm{CO} 2$, beyond which Earth's climate irreversibly is affected (Rockström et al., 2009). No boundary is defined for synthetic chemicals, but the scientific literature is rich in illustrations of how chemicals may threaten the environment, such as diminishing bee populations due to the use of neonicotinoids (EFSA, 2013). Society faces an urgent challenge in understanding how chemicals can be used sustainably without causing irreversible harm to the environment. Yet, effects of chemical pollution on ecosystem functioning remain understudied (Bernhardt et al., 2017) and the question is whether we actually have tools to understand how environmental systems are affected by synthetic chemicals (Figure 1).

The aim of this work is to identify and discuss current limitations in chemicals management and to highlight promising approaches for improvement. We discuss hazard and exposure assessments with the main focus on protection of the aquatic environment. We mainly base our analysis on EU chemicals and water legislations, with the assumption that the European case offers examples that can be applied on other parts of the world.

\section{Weaknesses in Current Chemicals Management}

\subsection{Outdated hazard criteria do not capture modern chemicals}

Current chemicals legislation is built around the identification of hazardous substances which' dispersion in the environment should be minimized, and hence regulated and phased out when socio-economic consequences are deemed acceptable. Hazard criteria include the properties environmental persistence, potential to bioaccumulate, and toxicity. The practices in chemical hazard assessment were originally designed to target chemicals with 
physicochemical properties similar to those of the persistent organic pollutants (POPs), such as DDT, as scientists produced evidence for their occurrence in and harm to the environment in the 1960's and 1970's (Matthies et al., 2016). Hence, both assessment of chemicals placed on the market, as well as monitoring actions have had a great focus on POP-type chemicals for decades. Today, chemicals in commerce have more diverse applications and span a wider range of physicochemical properties and legislation needs to evolve to keep up with this development (McLachlan, 2018; Reemtsma et al., 2016).

\subsection{Single chemical approach is slow and simplistic}

A major drawback of current chemicals regulation is that most chemicals are assessed individually, which is a slow process (European Commission, 2018), and not fit to keep up with chemical innovation and development of use. Further, it is commonly highlighted that chemicals occur in mixtures and may have additive or synergistic (or antagonistic) effects not captured in current risk assessments (SCHER, 2012). Transformation products formed after emissions to the environment are part of the mixture of chemicals but their contribution to risk is not properly assessed (Escher \& Fenner, 2011).

\subsection{Few endpoints are assessed and non-toxic effects ignored}

Toxicity assessments are carried out on few organisms, with focus on few toxicity mechanisms (called endpoints). The number of endpoints that could be affected by a certain substance or mixture is however endless and it is impossible to test all of them. This means that in principle, current management practice requires that effects on an ecosystem or global scale is anticipated based on only a few experiments with e.g. algae and Daphnia. One example that highlights the challenge to extrapolate risk from toxicity assessments to the real world is the unexpected near extinction of vultures feeding on cattle carcasses in India and Pakistan due to treatment of cattle by the anti-inflammatory painkiller diclofenac (Oaks et al., 2004). Adverse effects on Arctic organisms caused by chemicals used in agriculture or industry at temperate or tropical latitudes highlight the global aspect of contamination (AMAP, 2016). In addition to being toxic, chemicals can cause non-toxic effects and thereby harm essential processes in the environment, such as with the thinning of the ozone layer caused by chlorofluorocarbons used as refrigerants (MacGarvin et al., 2002). There is currently no mechanism in European legislation that aims at identifying chemicals that may exert non-biological effects to environmental systems.

\subsection{Environmental monitoring: focus on few chemicals}

In addition to hazard assessments based on inherent chemical properties, observations of effects and occurrence of chemicals in the environment constitute an important part of chemicals management. Such data provide information on current and past concentrations, which form the basis for assessments of environmental health and opportunities to follow changes over time. A fundamental weakness of monitoring as applied today is that the analytical methods require that you know what you look for. This so called target chemical analysis is expensive, and thus society needs to prioritize which chemicals to monitor. Currently, a great focus is on already well-known and in many cases regulated chemicals (Sobek et al., 2016). Problems associated with such prioritizations become evident from the EU water legislation (Water Frame Work Directive), which builds on the determination of ecological and chemical status of all waterbodies. Chemical status is determined through the calculation of risk quotients for a set of predefined priority substances (currently 45 for the entire union) (European Commission, 2000). At the same time, more than 900 synthetic chemicals are known to be present in inland surface water (Dulio et al., 2018) although this may just be the tip of the iceberg. Still, concentrations and quality standards for the limited list of priority substances govern decisions regarding need of action to improve chemical status. Currently, 38\% of all EU waterbodies have a chemical status that do not comply with good status criteria, but only 3\% fail to comply if two ubiquitous compounds/compound groups (the flame retardants PBDEs and mercury) are excluded from the evaluation (EEA, 2018). Hence, the addition or removal of only few chemicals can change the perception of the environmental health of a waterbody, and consequently, the strategy has been questioned (Brack et al., 2017, 2018).

\subsection{No chemical comes alone}

Problems arising from our limited knowledge of what chemicals are actually present in the environment, and our focus on defined lists 
of priority substances, are underlined by the common observation that biological effects measured in natural waters are far from explained by the chemicals typically included in monitoring programs or on priority lists (Neale et al., 2017; Tang et al., 2013). For instance, scientists recently demonstrated that the toxicity predicted based on 64 chemicals (including pharmaceuticals, pesticides and chemicals from consumer products) observed in monitoring programs corresponded to less than $1 \%$ of the observed non-receptor mediated toxicity in Australian drinking water (Tang et al., 2013). At the same time, Carvalho et al. (2014) found that a mixture of selected priority substances at their set thresholds for chronic effects, i.e. "safe" concentrations, in fact exerted significant effects on several endpoints in the applied suit of toxicity tests, highlighting the importance of addressing mixture effects when setting toxicological thresholds. This type of finding questions the relevance of the set threshold levels and again demonstrates the inherent uncertainty of a regulatory system that relies on individual assessment of few chemicals and few endpoints.

\subsection{Effect monitoring provides a more holistic view but cannot tie effect to chemical(s)}

Effect monitoring traditionally aims at gathering data on how organisms in the field are affected by stressors, and relies on observations of indicator species. In that perspective it provides a more holistic approach than measuring chemicals one by one, as observed effects can be the result of exposure to "all" chemicals present in the studied environment. Only few effect-based monitoring methods pin point effects of specific compounds (HELCOM, 2017). The usefulness of effect monitoring for determining chemical status and guiding management actions is also limited by the fact that the effect may be caused or enforced by other pressures in the environment, both biotic and abiotic (Zwart et al., 2018). To be guiding in management actions, further analyses to identify if/which chemicals are responsible for the observed effect may be required.

\subsection{Grand challenges of modern chemicals management}

Improving sustainable chemical use and innovation is challenging and involves many unknowns. In broad, it boils down to three grand challenges that society is facing in the progress towards protecting and understanding how the aquatic environment is affected by chemical pollution: i) identifying and regulating chemicals that should not enter the environment; ii) finding out which chemicals the environment is already exposed to; and iii) adequately linking data on total chemical exposure to ecological risk (Figure 2).

\section{Science-based Approaches for Improved Chemicals Management}

\subsection{Avoid emitting chemicals that do not degrade}

In the light of the realization that our system for chemical risk assessment will always suffer from large uncertainties and incompleteness, scientists have advocated a "better safe than sorry" approach (MacGarvin et al., 2002). It is argued that persistence in the environment should have a stronger emphasis in risk assessment, as persistent chemicals will remain in the environment for a very long time and accumulate as long as emissions continue (Reemtsma et al., 2016). Effects of chemicals that are degradable in the environment are reversible when sources are cut (MacLeod et al., 2014; Persson et al., 2013), whereas potential effects of persistent chemicals are irreversible, as the chemical will remain for decades, or even centuries to come in the environment. The industrial chemicals polychlorinated biphenyls (PCBs) offer an example of the irreversibility of potential effects caused by persistent chemicals. PCBs were banned almost globally in the 1970s-1980s and environmental concentrations have declined since then (AMAP, 2016). In the 1980s they were a major cause for e.g. declining seal populations in the Baltic Sea (Roos et al., 2012). Due to their environmental persistence, however, they still circulate the environment (Wania \& Su, 2004), and it was recently demonstrated that killer whale

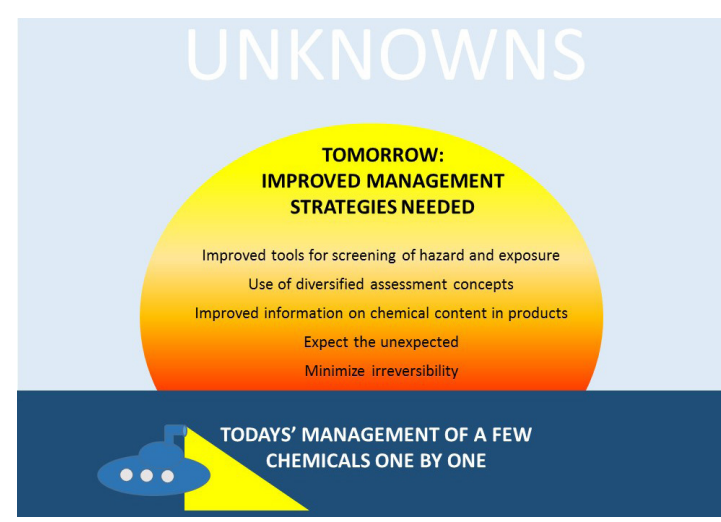

Figure 2. Society's chemicals management needs to improve in order to reduce risk caused by chemicals in aquatic ecosystems. 
populations near industrialized regions may in fact decline to extinction due to PCB-mediated effects on reproduction (Desforges et al., 2018).

\subsection{Suspect screening: measuring what is there}

Recent advancements in analytical chemistry open up for approaches that address the many unknown chemicals in the environment through screening of a high number of chemicals at the same time. Suspect screening is based on libraries containing molecular structure information on known chemicals used as references to identify chemicals in a sample, whereas non-target screening starts without any a priori information (Blum et al., 2017; Li et al., 2017; Schymanski et al., 2015). Rigorous non-target screening is still a complex and time-consuming task. Suspect screening is limited to the number and range of chemicals in the library, which may be skewed towards chemicals or compound classes that are already considered of environmental concern. Still, this is a powerful tool that can help identify many chemicals in the environment to a lower cost than traditional target analysis (Brack et al., 2018).

\subsection{Exposure modelling: predicting what is there}

Another approach to identify the chemicals amongst the thousands in commerce that warrant further risk assessments is to model emissions and exposure. Many efforts have aimed to extract potentially hazardous chemicals from big data sets of chemical structure information using models to predict physical chemical properties, which govern transport and ultimate fate in the environment (Arnot et al., 2012; Brown \& Wania, 2008; McLachlan et al., 2014; Muir \& Howard, 2006; Nendza et al., 2013; Reppas-Chrysovitsinos et al., 2018). Although a useful concept, the strategy is limited by poor availability of data on emissions and use of chemicals and thus the step from hazardous property identification to estimation of environmental risk is challenging. As a consequence, modeled environmental concentrations can end up having uncertainty ranges of several orders of magnitude (McLachlan et al., 2014), which is of little help in risk assessments. Increased transparency on produced volumes and use of chemicals would significantly improve the applicability of exposure modelling.

\subsection{Using big data to build proxies for emissions}

Recently, the possibilities of using other indicators of chemical pollution have been explored. In one study, data on import and production of manufactured products in the EU over time (2003-2016) was combined with data on chemical content of the products, with the aim to link consumption patterns with chemical emissions (Bolinius et al., 2018). Data on chemical content in materials, articles and products however needs to be improved in order to open up for this type of indicator. In a similar manner, (Froemelt et al., 2018) demonstrate how data on income and socioeconomic factors can be used together with a Life Cycle Assessment to investigate how carbon emissions down to family or single person level are related to life style factors. Improved data on chemical content in manufactured products would open up for this kind of analysis also for chemicals.

\subsection{Specific toxicity: Pareto's rule rules. Or does it?}

It has been observed that for endpoints that address toxicity exerted through a specific mechanism, a small number of chemicals out of a broad mixture is often responsible for the toxic effect (Holmes et al., 2018; Posthuma et al., 2018; Tang et al., 2013), apparently following the Pareto principle stating that commonly $80 \%$ of an effect can be related to $20 \%$ of the chemicals (Kortenkamp et al., 2014). Which 20\% of the chemicals that are responsible for the effect depends on the applied toxicity test (Malaj et al., 2014). Hence, such findings demonstrate that also for mixtures, the risk depends on what endpoints are assessed. For specific endpoints, combining data on occurrence of chemicals with biomonitoring tools to identify the drivers of toxicity is a powerful approach, currently going through major technical advancements (Brack et al., 2018; Jahnke et al., 2018; Neale et al., 2017).

\subsection{Baseline toxicity: how much chemical pollution can the environment tolerate?}

An important toxicity pathway for organic chemicals in many organisms is their penetration into the cell membrane lipid bilayer causing loss of cell integrity (Schwarzenbach et al., 2003). This is the mechanism underlying baseline (non-receptor mediated) toxicity. Many environments are primarily exposed to chemicals below the threshold level for compound-specific toxicity and on a global scale, baseline toxicity may determine the overall toxic effect exerted by mixtures of innumerable chemicals (Escher et al., 2002). Baseline toxicity is additive and directly related to chemical activity which is also additive (Gobas et al., 2018; Mackay et al., 2011) and relates chemical concentration to its 
maximum solubility in the environmental media. Chemical activity offers an additional concept to link exposure of complex mixtures to effects and is a proposed next-generation tool in monitoring that can be used to evaluate the total chemical burden of environmental matrices (Gobas et al., 2018).

\subsection{Expect the unexpected}

The threat of the many unknown chemicals has been discussed lately as part of the planetary boundary concept (MacLeod et al., 2014; Persson et al., 2013). One condition for chemicals to pose a planetary boundary threat is that they have a disruptive effect on an essential environmental process (Persson et al., 2013). For example, the toxicity of pharmaceuticals to primary producers has been highlighted as a mechanism by which fundamental processes in the aquatic environment may be impacted (Guo et al., 2015). Assessing different types of chemical stress, looking for the unexpected and not only continuing with what was done in the past (Grandjean et al., 2011), is one component of environmental monitoring that needs to be further developed to detect more unexpected signs of chemical pollution.

\section{Outlook}

Novel tools and approaches are available in chemical hazard and exposure assessment; none of them is perfect, but they offer improvements compared to the current regulatory system, and importantly, will help move us away from the single chemical approach. Improved information on chemical content in materials, products and articles is necessary in order to reduce the many unknowns in predictions of emissions of chemicals. Despite substantially improved hazard and risk assessment procedures, we must acknowledge that no management system will be able to catch all potential risk caused by hazardous chemicals, as both presence of chemicals and in particular their potential effects are difficult to predict. To increase our chances of sufficient environmental protection requires a system that covers different aspects of the unknowns. It also highlights the need for strong proactive risk assessment procedures that minimize emissions of hazardous chemicals with a potential to cause irreversible effects in the environment. The great challenges ahead require that scientists from several disciplines work together with regulators, decision makers and industry to make progress towards understanding not only which chemicals are out there, but also what harm they may cause.

\section{References}

ARCTIC MONITORING AND ASSESSMENT PROGRAMME - AMAP. AMAP assessment 2015: temporal trends in persistent organic pollutants in the Arctic. Oslo: AMAP, 2016.

ARNOT, J.A., BROWN, T.N., WANIA, F., BREIVIK, K. and MCLACHLAN, M.S. Prioritizing chemicals and data requirements for screening-level exposure and risk assessment. Environmental Health Perspectives, 2012, 120(11), 1565-1570. http:// dx.doi.org/10.1289/ehp.1205355. PMid:23008278.

BERNHARDT, E.S., ROSI, E.J. and GESSNER, M.O. Synthetic chemicals as agents of global change. Frontiers in Ecology and the Environment, 2017, 15(2), 84-90. http://dx.doi.org/10.1002/fee.1450.

BLUM, K.M., ANDERSSON, P.L., RENMAN, G., AHRENS, L., GROS, M., WIBERG, K. and HAGLUND, P. Non-target screening and prioritization of potentially persistent, bioaccumulating and toxic domestic wastewater contaminants and their removal in on-site and large-scale sewage treatment plants. The Science of the Total Environment, 2017, 575, 265-275. http://dx.doi.org/10.1016/j.scitotenv.2016.09.135. PMid:27744155.

BOLINIUS, D., SOBEK, A., LÖF, M.F. and UNDEMAN, E. Evaluating the consumption of chemical products and articles as proxies for diffuse emissions to the environment. Environmental Science. Processes \& Impacts, 2018, 20(10), 1427 1440. http://dx.doi.org/10.1039/C8EM00270C. PMid:30207349.

BRACK, W., DULIO, V., ÅGERSTRAND, M., ALLAN, I., ALTENBURGER, R., BRINKMANN, M., BUNKE, D., BURGESS, R.M., COUSINS, I., ESCHER, B.I., HERNÁNDEZ, F.J., HEWITT, L.M., HILSCHEROVÁ, K., HOLLENDER, J., HOLLERT, H., KASE, R., KLAUER, B., LINDIM, C., HERrÁEZ, D.L., MIÈGE, C., MUNTHE, J., O'TOOLE, S., POSTHUMA, L., RÜDEL, H., SCHÄFER, R.B., SENGL, M., SMEDES, F., VAN DE MEENT, D., VAN DEN BRINK, P.J., VAN GILS, J., VAN WEZEL, A.P., VETHAAK, A.D., VERMEIRSSEN, E., VON DER OHE, P.C. and VRANA, B. Towards the review of the European Union Water Framework Directive: recommendations for more efficient assessment and management of chemical contamination in European surface water resources. The Science of the Total Environment, 2017, 576, 720-737. http://dx.doi.org/10.1016/j.scitotenv.2016.10.104. PMid:27810758.

BRACK, W., ESCHER, B.I., MÜLLER, E., SCHMITTJANSEN, M., SCHULZE, T., SLOBODNIK, J. and HOLLERT, H. Towards a holistic and solutionoriented monitoring of chemical status of European water bodies: how to support the EU strategy for 
a non-toxic environment? Environmental Sciences Europe, 2018, 30(1), 33. http://dx.doi.org/10.1186/ s12302-018-0161-1. PMid:30221105.

BROWN, T.N. and WANIA, F. Screening chemicals for the potential to be persistent organic pollutants: a case study of arctic contaminants. Environmental Science \& Technology, 2008, 42(14), 5202-5209. http:// dx.doi.org/10.1021/es8004514. PMid:18754370.

CARSON, R. Silent spring. Cambridge: Riverside Press, 1962.

CARVALHO, R.N., ARUKWE, A., AIT-AISSA, S., BADO-NILLES, A., BALZAMO, S., BAUN, A., BELKIN, S., BLAHA, L., BRION, F., CONTI, D., CREUSOT, N., ESSIG, Y., FERRERO, V.E.V., FLANDER-PUTRLE, V., FÜRHACKER, M., GRILLARI-VOGLAUER, R., HOGSTRAND, C., JONÁŠ, A., KHARLYNGDOH, J.B., LOOS, R., LUNDEBYE, A.-K., MODIG, C., OLSSON, P.-E., PILLAI, S., POLAK, N., POTALIVO, M., SANCHEZ, W., SCHIFFERLI, A., SCHIRMER, K., SFORZINI, S., STÜRZENBAUM, S.R., SØFTELAND, L., TURK, V., VIARENGO, A., WERNER, I., YAGUR-KROLL, S., ZOUNKOVÁ, R. and LETTIERI, T. Mixtures of chemical pollutants at european legislation safety concentrations: how safe are they? Toxicological Sciences, 2014, 141(1), 218-233. http://dx.doi.org/10.1093/toxsci/kfu118. PMid:24958932.

CHEMICAL ABSTRACT SERVICE - CAS [online]. 2018 [viewed 8 Feb. 2018]. Available from: https:// www.cas.org/support/documentation/chemicalsubstances

DESFORGES, J.P., HALL, A., MCCONNELL, B., ROSING-ASVID, A., BARBER, J.L., BROWNLOW, A., DE GUISE, S., EULAERS, I., JEPSON, P.D., LETCHER, R.J., LEVIN, M., ROSS, P.S., SAMARRA, F., VÍKINGSON, G., SONNE, C. and DIETZ, R. Predicting global killer whale population collapse from PCB pollution. Science, 2018, 361(6409), 1373-1376. http://dx.doi. org/10.1126/science.aat1953. PMid:30262502.

DULIO, V., VAN BAVEL, B., BRORSTRÖMLUNDÉN, E., HARMSEN, J., HOLLENDER, J., SCHLABACH, M., SLOBODNIK, J., THOMAS, K. and KOSCHORRECK, J. Emerging pollutants in the EU: 10 years of NORMAN in support of environmental policies and regulations. Environmental Sciences Europe, 2018, 30(1), 5. http://dx.doi.org/10.1186/s12302-018-0135-3. PMid:29568720.

ESCHER, B.I. and FENNER, K. Recent advances in environmental risk assessment of transformation products. Environmental Science \& Technology, 2011, 45(9), 3835-3847. http://dx.doi.org/10.1021/ es1030799. PMid:21473617.

ESCHER, B.I., EGGEN, R.I.L., SCHREIBER, U., SCHREIBER, Z., VYE, E., WISNER, B. and
SCHWARZENBACH, R.P. Baseline toxicity (narcosis) of organic chemicals determined by in vitro membrane potential measurements in energytransducing membranes. Environmental Science \& Technology, 2002, 36(9), 1971-1979. http://dx.doi. org/10.1021/es015844c. PMid:12026980.

EUROPEAN CHEMICALS AGENCY - ECHA. Registered substances [online]. Helsinki: ECHA, 2018 [viewed 21 Feb. 2019]. Available from: https://echa. europa.eu/information-on-chemicals/registeredsubstances

EUROPEAN COMMISSION. Directive 2000/60/ EC of the European Parliament and of the council of 23 October 2000 establishing a framework for community action in the field of water policy. Official Journal of the European Union, Brussels, 22 dec. 2000.

EUROPEAN COMMISSION. Commission general report on the operation of $R E A C H$ and review of certain elements conclusions and actions [online]. Brussels: European Commission, 2018 [viewed 8 Feb. 2019]. Available from: https://eur-lex. europa.eu/legal-content/EN/TXT/?WT.mc_ $\mathrm{id}=$ Twitter\&uri=COM:2018:116:FIN

EUROPEAN ENVIRONMENT AGENCY - EEA. European waters: assessment of status and pressures 2018 [online]. Copenhagen: European Environment Agency, 2018 [viewed 8 Feb. 2019]. Available from: https://www.eea.europa.eu/publications/state-ofwater

EUROPEAN FOOD SAFETY AUTHORITY - EFSA. EFSA identifies risks to bees from neonicotinoids [online]. Parma: EFSA, 2013 [viewed 21 Feb. 2019]. Available from: http://www.efsa.europa.eu/en/press/ news/130116

FROEMELT, A., DÜRRENMATT, D.J. and HELLWEG, S. Using data mining to assess environmental impacts of household consumption behaviors. Environmental Science \& Technology, 2018, 52(15), 8467-8478. http://dx.doi.org/10.1021/acs. est.8b01452. PMid:29933691.

GOBAS, F.A.P.C., MAYER, P., PARKERTON, T.F., BURGESS, R.M., VAN DE MEENT, D. and GOUIN, T. A chemical activity approach to exposure and risk assessment of chemicals: focus articles are part of a regular series intended to sharpen understanding of current and emerging topics of interest to the scientific community. Environmental Toxicology and Chemistry, 2018, 37(5), 1235-1251. http://dx.doi. org/10.1002/etc.4091. PMid:29697868.

GRANDJEAN, P., ERIKSEN, M.L., ELLEGAARD, O. and WALLIN, J.A. The Matthew effect in environmental science publication: a bibliometric analysis of chemical substances in journal articles. Environmental Health: A Global Access Science Source, 2011, 10(1), 96-103. http://dx.doi. org/10.1186/1476-069X-10-96. PMid:22074398. 
GUO, J., BOXALL, A. and SELBY, K. Do pharmaceuticals pose a threat to primary producers? Critical Reviews in Environmental Science and Technology, 2015, 45(23), 2565-2610. http://dx.doi.org/10.1080/10643389.2 015.1061873 .

HELCOM. Helsinki Commission. TBT and imposex: HELCOM core indicator report. Helsinki: HELCOM, 2017.

HOLMES, C.M., BROWN, C.D., HAMER, M., JONES, R., MALTBY, L., POSTHUMA, L., SILBERHORN, E., TEETER, J.S., WARNE, M.S.J. and WELTJE, L. Prospective aquatic risk assessment for chemical mixtures in agricultural landscapes. Environmental Toxicology and Chemistry, 2018, 37(3), 674-689. http://dx.doi.org/10.1002/ etc.4049. PMid:29193235.

JAHNKE, A., SOBEK, A., BERGMANN, M., BRÄUNIG, J., LANDMANN, M., SCHÄFER, S. and ESCHER, B.I. Emerging investigator series: effect-based characterization of mixtures of environmental pollutants in diverse sediments. Environmental Science. Processes \& Impacts, 2018, 20(12), 1667-1679. http://dx.doi.org/10.1039/ C8EM00401C. PMid:30346461.

JENSEN, S., JOHNELS, A.G., OLSSON, M. and OTTERLIND, G. DDT and PCB in marine animals from swedish waters. Nature, 1969, 224(5216), 247-250. http://dx.doi.org/10.1038/224247a0. PMid:5388040.

KORTENKAMP, A., SCHOLZE, M. and ERMLER, $S$. Mind the gap: can we explain declining male reproductive health with known antiandrogens? Reproduction, 2014, 147(4), 515-527. http://dx.doi. org/10.1530/REP-13-0440. PMid:24435164.

LI, Z., KASERZON, S.L., PLASSMANN, M.M., SOBEK, A., GÓMEZ RAMOS, M.J. and RADKE, M. A strategic screening approach to identify transformation products of organic micropollutants formed in natural waters. Environmental Science. Processes \& Impacts, 2017, 19(4), 488498. http://dx.doi.org/10.1039/C6EM00635C. PMid:28233005.

MACGARVIN, M., LAMBERT, B., INFANTE, P., GREENBERG, M., GEE, D., KOPPE, J.G., KEYS, J., FARMAN, J., IBARRETA, D., SWAN, S.H., EDQVIST, L.-E., PEDERSEN, K.B., SEMB, A., VON KRAUSS, M.K., HARREMOES, P., GILBERTSON, M., SANTILLO, D., JOHNSTON, P., LANGSTON, W.J., BRIDGES, O., VAN ZWANENBERG, P. and MILLSTONE, E. Late lessons from early warnings: the precautionary principle. Copenhagen: European Environment Agency, 2002. Environmental Issue report n. ${ }^{\circ}$ 22/2001.

MACKAY, D., ARNOT, J.A., WANIA, F. and BAILEY, R.E. Chemical activity as an integrating concept in environmental assessment and management of contaminants. Integrated Environmental Assessment and Management, 2011, 7(2), 248-255. http://dx.doi. org/10.1002/ieam.139. PMid:20836055.

MACLEOD, M., BREITHOLTZ, M., COUSINS, I.T., WIT, C.A., PERSSON, L.M., RUDÉN, C. and MCLACHLAN, M.S. Identifying chemicals that are planetary boundary threats. Environmental Science \& Technology, 2014, 48(19), 11057-11063. http:// dx.doi.org/10.1021/es501893m. PMid:25181298.

MALAJ, E., VON DER OHE, P.C., GROTE, M., KÜHNE, R., MONDY, C.P., USSEGLIOPOLATERA, P., BRACK, W. and SCHÄFER, R.B. Organic chemicals jeopardize the health of freshwater ecosystems on the continental scale. Proceedings of the National Academy of Sciences of the United States of America, 2014, 111(26), 9549-9554. http://dx.doi. org/10.1073/pnas.1321082111. PMid:24979762.

MATTHIES, M., SOLOMON, K., VIGHI, M., GILMAN, A. and TARAZONA, J.V. The origin and evolution of assessment criteria for Persistent, Bioaccumulative and Toxic (PBT) chemicals and Persistent Organic Pollutants (POPs). Environmental Science. Processes \& Impacts, 2016, 18(9), 11141128. http://dx.doi.org/10.1039/C6EM00311G. PMid:27477634.

MCLACHLAN, M.S. Can the Stockholm convention address the spectrum of chemicals currently under regulatory scrutiny? Advocating a more prominent role for modeling in POP screening assessment. Environmental Science. Processes \& Impacts, 2018, 20(1), 32-37. http://dx.doi.org/10.1039/ C7EM00473G. PMid:29322155.

MCLACHLAN, M.S., KIERKEGAARD, A., RADKE, M., SOBEK, A., MALMVÄRN, A., ALSBERG, T., ARNOT, J.A., BROWN, T.N., WANIA, F., BREIVIK, K. and XU, S. Using model-based screening to help discover unknown environmental contaminants. Environmental Science \& Technology, 2014, 48(13), 7264-7271. http:// dx.doi.org/10.1021/es5010544. PMid:24869768.

MUIR, D.C.G. and HOWARD, P.H. Are there other persistent organic pollutants? A challenge for environmental chemists. Environmental Science \& Technology, 2006, 40(23), 7157-7166. http://dx.doi. org/10.1021/es061677a. PMid:17180962.

NEALE, P.A., ALTENBURGER, R., AÏT-AÏSSA, S., BRION, F., BUSCH, W., DE ARAGÃO UMBUZEIRO, G., DENISON, M.S., DU PASQUIER, D., HILSCHEROVÁ, K., HOLLERT, H., MORALES, D.A., NOVÁK, J., SCHLICHTING, R., SEILER, T.-B., SERRA, H., SHAO, Y., TINDALL, A.J., TOLLEFSEN, K.E., WILLIAMS, T.D. and ESCHER, B.I. Development of a bioanalytical test battery for water quality monitoring: Fingerprinting identified micropollutants and their contribution to effects in surface water. Water Research, 2017, 123, 734-750. 
http://dx.doi.org/10.1016/j.watres.2017.07.016. PMid:28728110.

NENDZA, M., GABBERT, S., KÜHNE, R., LOMBARDO, A., RONCAGLIONI, A., BENFENATI, E., BENIGNI, R., BOSSA, C., STREMPEL, S., SCHERINGER, M., FERNÁNDEZ, A., RALLO, R., GIRALT, F., DIMITROV, S., MEKENYAN, O., BRINGEZU, F. and SCHÜÜRMANN, G. A comparative survey of chemistry-driven in silico methods to identify hazardous substances under REACH. Regulatory Toxicology and Pharmacology, 2013, 66(3), 301-314. http://dx.doi.org/10.1016/j.yrtph.2013.05.007. PMid:23707536.

OAKS, J.L., GILBERT, M., VIRANI, M.Z., WATSON, R.T., METEYER, C.U., RIDEOUT, B.A., SHIVAPRASAD, H.L., AHMED, S., IQBAL CHAUDHRY, M.J., ARSHAD, M., MAHMOOD, S., ALI, A. and AHMED KHAN, A. Diclofenac residues as the cause of vulture population decline in Pakistan. Nature, 2004, 427(6975), 630-633. http:// dx.doi.org/10.1038/nature02317. PMid:14745453.

PERSSON, L.M., BREITHOLTZ, M., COUSINS, I.T., DE WIT, C.A., MACLEOD, M. and MCLACHLAN, M.S. Confronting unknown planetary boundary threats from chemical pollution. Environmental Science \& Technology, 2013, 47(22), 12619-12622. http://dx.doi.org/10.1021/ es402501c. PMid:23980998.

POSTHUMA, L., BROWN, C.D., DE ZWART, D., DIAMOND, J., DYER, S.D., HOLMES, C.M., MARSHALL, S. and BURTON JUNIOR, G.A. Prospective mixture risk assessment and management prioritizations for river catchments with diverse land uses. Environmental Toxicology and Chemistry, 2018, 37(3), 715-728. http://dx.doi.org/10.1002/etc.3960. PMid:28845901.

REEMTSMA, T., BERGER, U., ARP, H.P., GALLARD, H., KNEPPER, T.P., NEUMANN, M., QUINTANA, J.B. and VOOGT, P. Mind the gap: persistent and mobile organic compounds-water contaminants that slip through. Environmental Science \& Technology, 2016, 50(19), 1030810315. http://dx.doi.org/10.1021/acs.est.6b03338. PMid:27571393.

REPPAS-CHRYSOVITSINOS, E., SOBEK, A. and MACLEOD, M. In silico screening-level prioritization of 8468 chemicals produced in OECD countries to identify potential planetary boundary threats. Bulletin of Environmental Contamination and Toxicology, 2018, 100(1), 134-146. http://dx.doi. org/10.1007/s00128-017-2253-9. PMid:29285590.

ROCKSTRÖM, J., STEFFEN, W., NOONE, K., PERSSON, A.., CHAPIN, F.S., LAMBIN, E.F., LENTON, T.M., SCHEFFER, M., FOLKE, C., SCHELLNHUBER, H.J., NYKVIST, B., DE WIT, C.A., HUGHES, T., VAN DER LEEUW,
S., RODHE, H., SÖRLIN, S., SNYDER, P.K., COSTANZA, R., SVEDIN, U., FALKENMARK, M., KARLBERG, L., CORELL, R.W., FABRY, V.J., HANSEN, J., WALKER, B., LIVERMAN, D., RICHARDSON, K., CRUTZEN, P. and FOLEY, J.A. A safe operating space for humanity. Nature, 2009, 461(7263), 472-475. http://dx.doi. org/10.1038/461472a. PMid:19779433.

ROOS, A.M., BÄCKLIN, B.-M.V.M., HELANDER, B.O., RIGÉT, F.F. and ERIKSSON, U.C. Improved reproductive success in otters (Lutra lutra), grey seals (Halichoerus grypus) and sea eagles (Haliaeetus albicilla) from Sweden in relation to concentrations of organochlorine contaminants. Environmental Pollution, 2012, 170, 268-275. http://dx.doi.org/10.1016/j.envpol.2012.07.017. PMid:22842056.

SCHWARZENBACH, R.P., GSCHWEND, P.M. and IMBODEN, D. Environmental organic chemistry. 2nd ed. New York: John Wiley \& Sons, 2003.

SCHYMANSKI, E.L., SINGER, H.P., SLOBODNIK, J., IPOLYI, I.M., OSWALD, P., KRAUSS, M., SCHULZE, T., HAGLUND, P., LETZEL, T., GROSSE, S., THOMAIDIS, N.S., BLETSOU, A., ZWIENER, C., IBANEZ, M., PORTOLES, T., DE BOER, R., REID, M.J., ONGHENA, M., KUNKEL, U., SCHULZ, W., GUILLON, A., NOYON, N., LEROY, G., BADOS, P., BOGIALLI, S., STIPANICEV, D., ROSTKOWSKI, P. and HOLLENDER, J. Non-target screening with highresolution mass spectrometry: critical review using a collaborative trial on water analysis. Analytical and Bioanalytical Chemistry, 2015, 407(21), 6237-6255. http://dx.doi.org/10.1007/s00216-015-8681-7. PMid:25976391.

SCIENTIFIC COMMITTEE ON HEALTH AND ENVIRONMENTAL RISKS - SCHER. Scientific Committee on Emerging and Newly Identified Health Risks - SCENIHR. Scientific Committee on Consumer Safety-SCCS. Opinion on the toxicity and assessment of chemical mixtures. Brussels: European Commission, 2012.

SOBEK, A., BEJGARN, S., RUDÉN, C. and BREITHOLTZ, M. The dilemma in prioritizing chemicals for environmental analysis: known versus unknown hazards. Environmental Science. Processes \& Impacts, 2016, 18(8), 1104. http://dx.doi. org/10.1039/C6EM90023B. PMid:27222376.

STEFFEN, W., BROADGATE, W., DEUTSCH, L., GAFFNEY, O. and LUDWIG, C. The trajectory of the anthropocene: the great acceleration. The Anthropocene Review, 2015, 2(1), 81-98. http:// dx.doi.org/10.1177/2053019614564785.

TANG, J.Y.M., MCCARTY, S., GLENN, E., NEALE, P.A., WARNE, M.S.J. and ESCHER, B.I. Mixture effects of organic micropollutants present in water: Towards the development of effect-based water quality trigger values for baseline toxicity. Water 
Research, 2013, 47(10), 3300-3314. http://dx.doi. org/10.1016/j.watres.2013.03.011. PMid:23618317.

THE EUROPEAN CHEMICAL INDUSTRY COUNCIL - CEFIC. Facts and figures [online]. Brussels: CEFIC, 2018 [viewed 8 Feb. 2019]. Available from: http://www.cefic.org/Facts-and-Figures/

UNITED NATIONS ENVIRONMENT PROGRAMME - UNEP. Global chemicals outlook: towards sound management of chemicals. Nairóbi: UNEP, 2013.

WANIA, F. and SU, Y. Quantifying the global fractionation of polychlorinated biphenyls. Ambio, 2004, 33(3), 161-168. http://dx.doi.org/10.1579/0044-744733.3.161. PMid:15151387.

WILSON, M.P. and SCHWARZMAN, M.R. Toward a New U.S. chemicals policy: rebuilding the foundation to advance new science, green chemistry, and environmental health. Environmental Health Perspectives, 2009, 117(8), 1202-1209. http://dx.doi. org/10.1289/ehp.0800404. PMid:19672398.

ZWART, D., ADAMS, W., GALAY BURGOS, M., HOLLENDER, J., JUNGHANS, M., MERRINGTON, G., MUIR, D., PARKERTON, T., DE SCHAMPHELAERE, K.A.C., WHALE, G. and WILLIAMS, R. Aquatic exposures of chemical mixtures in urban environments: approaches to impact assessment. Environmental Toxicology and Chemistry, 2018, 37(3), 703-714. http://dx.doi. org/10.1002/etc.3975. PMid:28861906.

Received: 25 February 2019 Accepted: 30 May 2019 